\title{
A Study on the Relationship of Socio Economic Status with Knowledge and Adoption of Post-harvest Management Practices among the Mango Growers in Jammu District
}

\author{
Pratima Rana $^{1 *}$ and Poonam Parihar $^{2}$ \\ ${ }^{1}$ Department of Agricultural Communication, GBPUAT, Pantnagar, \\ U.S. Nagar, Uttarakhand, India \\ ${ }^{2}$ Department of Agricultural Extension Education, SKUAST, Jammu; Chatha, \\ Jammu \& Kashmir, India \\ *Corresponding author
}

Keywords

Post harvest management practices, Adoption, Knowledge, perishable

Article Info

Accepted:

07 November 2020

Available Online:

10 December 2020

\begin{abstract}
A B S T R A C T
Mango (Mangifera indica L.) occupies a pre-eminent place amongst the sub-tropical fruits grown in Jammu region and is extensively grown crop in this region. The horticulture crops are perishable in nature and they require special attention in their harvesting, handling, packaging, storage and processing operations, therefore post-harvest management practices of a crop is done to prolong the storage life, freshness and an attractive appearance. A study was conducted on 80 mango growers which were selected on the basis of proportionate random sampling were interviewed using a structured interview schedule. The results showed that one-third of respondents were noticed to fall under medium age interval and half of the respondents were having small landholdings. Rain water was the main source of irrigation. Area under mango orchards was 1.23 ha. Adoption of post-harvest management practices like storage facility were significantly determined by landholdings, number of trees, distance from market and artificial ripening were significantly determined by education, distance of market and extension contact. Education affected the knowledge of the respondents regarding post harvest management practices.
\end{abstract}

\section{Introduction}

India, with diverse soil and climate types comprising several agro-ecological regions, provides ample opportunity to grow a variety of crops. Horticultural crops form a significant part of total agricultural produce in the country and become key drivers of economic development in many of the states in the country. They contribute 30.4 per cent to Agriculture Gross domestic product (GDP) (Economic Survey 2018-19). Among the major fruits of India, Mango (Mangifera indica L.) is known as the king of fruits. India is the largest producer and consumer of mangoes and Indian mangoes are known for their taste and aroma throughout the world. The horticulture crops are perishable in nature 
and require special attention. Post-harvest management practices mean the handling of an agricultural product after harvest to prolong storage life, freshness and an attractive appearance and also reduce the losses. Importance of post harvest management practices in mango lies in the fact that it has the capability to meet requirement of growing population by elimination losses, making more nutritive items from its pulp by proper processing and fortification. Even though, numbers of post harvest management practices are being recommended to maximize benefits, the mango growers are not adopting the recommended practices. The thorough knowledge of the post harvest management practices by the mango growers/orchardists would help mango growers in reducing the loss and obtaining the higher yields. Thus the study provides empirical feedback to post harvest management scientists to reorient the research priorities.

The main objectives of the study include to study socio-economic characteristics of the mango growers. And also to determine the relationship of socio-economic characteristics with knowledge and adoption of post harvest management practices of mango growers.

\section{Materials and Methods}

The state of Jammu and Kashmir has three provinces namely Jammu province, the Kashmir Valley and Ladakh offering a rich diversity in landscapes, region and people. The present study was conducted in the subtropical areas of Jammu district of the Jammu and Kashmir State. The research design employed for the study was descriptive design. The highest mango cultivating areas of Marh, Balwal, Khour, Akhnoor, and Dansal were selected out of eight blocks for the study purposively. Proportionate random sampling technique was applied to select a total sample of 80 respondents. The orchardist whose numbers of mango plants were 50 and more than 50 are considered for the study. The final selection of 80 respondents was conducted through random number generator from the above selected blocks.

\section{Results and Discussion}

\section{Socio-economic profile of the respondents}

The data in table 1 reveals that, in Jammu district overall 37.50 per cent of the respondents were in the middle age group of 30-50 years. Overall average age of the respondents in Jammu district was 58.56 years (10.83). The results are in conformity with Nagesh (2006), Basanayak (2009), Bennur (2011), Radhakrishnan et al., (2014). With regard to education of head of the family, overall average number of formal schooling years completed was seven years and 27.50 per cent of the respondents were illiterate.

The probable reason for majority of farmers to be in illiterate category might be the illiteracy of their parents, non-realization of importance of formal education and low annual income. The average total family size in case of Jammu district was seven members (Meena et al., (2009) and Mehta and Sonaware (2012)). Overall average operational land holding in the Jammu district was 2.05 hectares with an irrigated area of 51.25 per cent and unirrigated area of 48.75 per cent. Further, in case of farm size, in Jammu district, overall 15 per cent respondents fall under the marginal category having less than one ha of land, about 47.50 per cent respondents were in small category having one to two ha of land.

\section{Farmers' sources of irrigation}

Table 2 depicts the sources of irrigation of sampled farmers under study. In Jammu district, majority of the respondents $(48.75 \%)$ 
were dependent on rainwater for irrigation, whereas 35.00 per cent, 10.00 per cent and 6.25 per cent respondents were having facility of electric tube well, canal water and water harvesting structure (talab) respectively.

Table.1 Descriptive statistics regarding socio-economic status of the farmer

\begin{tabular}{|c|c|}
\hline Parameter & Total $(n=80)$ \\
\hline \multicolumn{2}{|l|}{ Categorization of age ( $\%$ farmer) } \\
\hline 30-50 years & $16(20.00)$ \\
\hline 50-59 years & $19(23.75)$ \\
\hline $59-70$ years & $30(37.50)$ \\
\hline 70-82 years & $15(18.75)$ \\
\hline Mean $\pm S . D_{x}$ & $58.56 \pm 10.83$ \\
\hline \multicolumn{2}{|l|}{ Education level } \\
\hline Illiterate & $22(27.50)$ \\
\hline Primary & $08(10.00)$ \\
\hline Middle & $16(20.00)$ \\
\hline Matric & $19(23.75)$ \\
\hline $10+2$ & $07(8.75)$ \\
\hline Graduate and above & $08(10.00)$ \\
\hline Mean $\pm S . D_{x}$ & $7.03 \pm 4.98$ \\
\hline \multicolumn{2}{|l|}{ Size of family } \\
\hline 1-7 members & $45(56.25)$ \\
\hline 7-13 members & $28(35.00)$ \\
\hline 13-23 members & 07 (8.75) \\
\hline Average number of adults & 06 \\
\hline Average number of children & $\mathbf{0 2}$ \\
\hline Average family size (Mean $\left.\pm S . D_{*}\right)$ & $6.99 \pm 3.69$ \\
\hline \multicolumn{2}{|c|}{ Average operational land holding (ha) } \\
\hline Total area & $2.05 \pm 2.55$ \\
\hline Irrigated & $41(51.25)$ \\
\hline Unirrigated & $39(48.75)$ \\
\hline \multicolumn{2}{|l|}{ Categorization of farm size* } \\
\hline Marginal (<1 ha) & $12(15.00)$ \\
\hline Small (1-2 ha) & $38(47.50)$ \\
\hline Semi medium (2-4 ha) & $21(26.25)$ \\
\hline Medium (4-!0 ha) & $07(8.75)$ \\
\hline Large (>10 ha) & $02(2.50)$ \\
\hline
\end{tabular}

Figures in the parentheses are percentages

*Categorization of farm size as per MoA (2014) 
Table.2 Source of irrigation

\begin{tabular}{|l|l|}
\hline Source of Irrigation & Total $(\mathbf{n}=\mathbf{8 0})$ \\
\hline Canal water & $\mathbf{0 8}(\mathbf{1 0 . 0 0 )})$ \\
\hline Electric tube well & $\mathbf{2 8}(\mathbf{3 5 . 0 0})$ \\
\hline Rain water & $\mathbf{3 9}(\mathbf{4 8 . 7 5 )}$ \\
\hline Talab/ water harvesting structure & $\mathbf{0 5}(\mathbf{6 . 2 5})$ \\
\hline
\end{tabular}

Figures in the parentheses are percentages

Table.3 Occupational status of farmers

\begin{tabular}{|l|l|}
\hline Occupational Status & Total $(\mathbf{n}=\mathbf{8 0})$ \\
\hline Categorization of workforce (no.) & \\
\hline Farmer & $\mathbf{4 7}(\mathbf{5 8 . 7 5})$ \\
\hline Farmer + service & $\mathbf{2 8}(\mathbf{3 5 . 0 0})$ \\
\hline Farmer + business & $\mathbf{0 5}(6.25)$ \\
\hline Total family size (number) & $\mathbf{5 5 9}$ \\
\hline Work force (number) & $\mathbf{2 2 2}$ \\
\hline
\end{tabular}

Figures in the parentheses are percentages

Table.4 Source of information of the mango growers

\begin{tabular}{|l|l|}
\hline Extension Contact & Total $(\mathbf{n}=\mathbf{8 0})$ \\
\hline Horticulture department & $\mathbf{6 8}(\mathbf{8 5 . 0 0})$ \\
\hline Agri. Department, KVK, University & $\mathbf{0 0}(\mathbf{0 . 0 0})$ \\
\hline Fertilizers and pesticide shop & $\mathbf{0 0}(\mathbf{0 . 0 0})$ \\
\hline Farmer and neighbors' & $\mathbf{1 2}(\mathbf{1 5 . 0 0})$ \\
\hline
\end{tabular}

Figures in the parentheses are percentages

Table.5 Association of the knowledge with education of the mango growers

\begin{tabular}{|l|l|l|l|l|}
\hline Parameter & Knowledge & & Total \\
\hline Education & Low & Medium & High & \\
\hline Illiterate & $14(8.25)$ & $05(9.08)$ & $03(4.68)$ & $\mathbf{2 2}$ \\
\hline Primary & $06(3.0)$ & $02(3.3)$ & $00(1.7)$ & $\mathbf{0 8}$ \\
\hline Middle & $04(6.0)$ & $12(6.6)$ & $00(3.4)$ & $\mathbf{1 6}$ \\
\hline Matric & $04(7.13)$ & $08(7.84)$ & $07(4.04)$ & $\mathbf{1 9}$ \\
\hline $\mathbf{1 0 + 2}$ & $02(2.63)$ & $05(2.89)$ & $00(1.49)$ & $\mathbf{0 7}$ \\
\hline graduate and above & $00(3.0)$ & $01(3.3)$ & $07(1.7)$ & $\mathbf{0 8}$ \\
\hline Total & $\mathbf{3 0}$ & $\mathbf{3 3}$ & $\mathbf{1 7}$ & $\mathbf{8 0}$ \\
\hline
\end{tabular}

The association is statistically significant as the calculated value $\chi^{2}$ is 47.38 which is greater than table value of $\chi^{2}$ at $\mathrm{p}<0.05$ for d.f. $=10$ is 18.31

All figures in the parenthesis are expected frequencies 


\section{Occupational status of the mango growers}

The results presented in table 3 reveals that, in case of overall Jammu districts 47 farmers $(58.75 \%)$ were depended exclusively on agriculture for source of income, while 28 farmers $(35.00 \%)$ were depended on agriculture + service and only 5 farmers $(6.25 \%)$ were depended on agriculture + business for source of income respectively. The results are in conformity with Nagesh (2006).

The results indicated that the farmers are following the traditional system by relying on agriculture for their livelihood.

Source of information of the mango growers

The data in table 4 reveals that, in Jammu district, majority (85 per cent) of the respondents had contact with Horticulture department, 15.00 per cent with fellow farmers and neighbors'. This indicates that Horticulture Department is performing well in the Jammu district.

\section{Association of the knowledge with the} socio-economic factors

The data in table 5 depicts that the association is determined by using chi-square method and it was observed that the association of knowledge with the education of the respondents is statistically significant as the calculated value is greater than the table value. While the association of knowledge with age, family size and occupation is not statistically significant as the calculated value is not greater than the table value.

\section{Factors affecting adoption of post harvest management practices in mango}

Binary logistic regression model was applied to ascertain the factors affecting the adoption of post harvest management practices in mango. The variables of washing, grading, storing, storage facility, artificial ripening and chemical use, were kept as the dependent variables and the independent variables were age, education, occupation, family size, landholdings, irrigation, extension contacts, number of trees, yield per tree, distance from market and income source.

Adoption of washing: In case of adoption of washing, which was the dependent variable, none of the independent variables were statistically significant. The Nagelkerke $\mathrm{R}^{2}$ of the model was $0.325, \chi^{2}$ was 20.119 and the $p$ value was 0.126 . This is due to the fact that mango growers usually pack their produce immediately after harvesting.

Adoption of grading: In case of adoption of grading, which was the dependent variable, none of the independent variables were statistically significant. The Nagelkerke $\mathrm{R}^{2}$ of the model was $1.000, \chi^{2}$ was 31.762 and the $p$ value was 0.004 .

Adoption of storing: In case of adoption of storing, which was the dependent variable, none of the independent variables were statistically significant. The Nagelkerke $\mathrm{R}^{2}$ of the model was $1.000, \chi^{2}$ was 56.274 and the $p$ value was 0.00 . Mostly farmers sell their produce just after harvesting.

Adoption of storage facility: In case of adoption of storage facility, which was the dependent variable, some of the independent variables were statistically significant like family size was significant at 0.043 , landholding was significant at 0.013 , number of trees was significant at 0.028 and distance from market was significant at 0.038 . The Nagelkerke $\mathrm{R}^{2}$ of the model was $0.798, \chi^{2}$ was 66.128 and the $p$ value was 0.00 .

Adoption of artificial ripening: In case of 
adoption of artificial ripening, which was the dependent variable, some of the independent variables were statistically significant like education was significant at 0.039 , extension contact was significant at 0.037 and distance from market was significant at 0.040. The Nagelkerke $R^{2}$ of the model was $0.244, \chi^{2}$ was 16.134 and the $p$ value was 0.305. Education and extension contact aware the farmers about the ripening methods.

Adoption of pesticides and insecticides use:

In case of adoption of pesticides and insecticides use, which was the dependent variable, none of the independent variables were statistically significant. The Nagelkerke $\mathrm{R}^{2}$ of the model was $1.000, \chi^{2}$ was 52.013 and the $p$ value was 0.00 .

The study results about the factors affecting the adoption of post harvest management practices in mango was in conformity with Jadhav et al., (2009), Bano, F. (2014). It is to be concluded on the basis of the findings that the respondents had high level of farming experience as mango orchardists and were having marginal and small land holding but majority of respondents are illiterate.

The adoption was poor in case of washing of fruits, control of sap burning, use of potassium permanganate etc. It is also reported that certain variables had significant relationship with the adoption of storage facility and artificial ripening like respondents' number of trees, education, extension contacts, landholdings, family size and distance of village from market and fertilizer shop.

\section{Acknowledgement}

The help and support provided by Block Development office, Jammu, Jammu \&
Kashmir and Department of Agricultural Extension Education, Sher-e-Kashmir University of Agricultural Sciences and Technology are gratefully acknowledged.

\section{References}

Bano, F. 2014. Adoption of the recommended technological innovation by the mango orchardists in Jammu and Samba districts of the Jammu and Kashmir state. (M.Sc. thesis. SKUAST- Jammu, India).

Basanayak, R. 2009. An Analysis of Technological Gap in Papaya Cultivation in Bidar and Gulbarga Districts of North Karnataka. (M.Sc. thesis. University of Agricultural Sciences, Dharwad, India).

Bennur, A.K. 2011. A Study on Entrepreneurial Qualities and Adoption Behaviour of Banana Growers. (M.Sc. thesis. University of Agricultural Sciences, Dharwad, India).

Jadhav, V.D. Thombre, B.M. and Mande, J.V. 2009. Adoption of mango post harvest technology by farm women of Latur district of Maharashtra. Agriculture Update, 4(3\&4):255-258.

Meena, M.S., Kumar, Ashwani., Singh, K.M. and Meena, H.R. 2009. Farmers' Attitude towards Post-Harvest Issues of Horticultural Crops. Indian Research Journal of Extension Education, 9(3):15-19.

Mehta, B.M. and Sonawane, M. (2012a). Characteristic and adoption behaviour of mango growers in Valsad district of Gujrat. Agriculture Update, 7(1\&2):3741.

Mehta, B.M. and Sonawane, M. (2012b). Entrepreneurial behavior of mango grower of valsad district of Gujrat state. Indian Research Journal of Extension Education, 12(1).

Nagesh, B. 2006. Study on Entrepreneurial 
Behaviour of Pomegranate Growers in Bagalkot District of Karnataka. M.Sc. thesis. University of Agricultural Sciences, Dharwad, India.

Radhakrishnan, A., Meti. S.K. and Goudappa, S.B. 2014. Information management behaviour of papaya growers of Karnataka: A comparative study. Indian
Research Journal of Extension Education, 14(2):31-35.

https://www.indiabudget.gov.in/budget201819/economicsurvey/index.php (economic survey, 2018-19) retrieved on $04 / 04 / 2019$

\section{How to cite this article:}

Pratima Rana and Poonam Parihar. 2020. A Study on the Relationship of Socio Economic Status with Knowledge and Adoption of Post-harvest Management Practices among the Mango Growers in Jammu District. Int.J.Curr.Microbiol.App.Sci. 9(12): 409-415. doi: https://doi.org/10.20546/ijcmas.2020.912.051 